\title{
Pola penanganan korban perilaku perundungan (bullying) pada siswa SMPN Kecamatan Kediri Kabupaten Lombok Barat
}

\author{
Muhammad Mabrur Haslan \\ FKIP PPKn, Universitas Mataram \\ Kota Mataram, Indonesia \\ mabrum41@.gmail.com
}

\author{
Ahmad Fauzan \\ FKIP PPKn, Universitas Mataram \\ Kota Mataram, Indonesia \\ ahmadfauzan18@unram.ac.id \\ I Nengah Agus Tripayana \\ FKIP PPKn, Universitas Mataram \\ Kota Mataram, Indonesia \\ tripayanaagus@unram.ac.id
}

\begin{abstract}
This study aims (1) to describe the pattern of handling victims of bullying in SMP Negeri Kediri District, West Lombok Regency (2) to identify obstacles in the handling of victims of bullying in SMP Negeri students in Kediri District, Regency. West Lombok. The method used in this research is a qualitative approach. The research location was carried out in SMPs throughout Kediri District, West Lombok Regency. Determination of informants using snowball sampling. Data collection methods are depth interviews), observation and documentation. The Research Result have been analyzed so that it is obtained: (1) conducting information selection (supporting network). (2) conducting the mentoring or peer monitoring stage. (3) make use of peer group or peer befriending. (4) conduct counseling and mediation. (5) conduct socialization and control, namely efforts to provide the understanding and continuous monitoring of victims of bullying.
\end{abstract}

Keywords: handling pattern; victims of bullying behavior;

\begin{abstract}
Abstrak
Penelitian ini bertujuan (1) mendeskripsikan pola penanganan korban perilaku (bullying) pada siswa SMP Negeri Kecamatan Kediri Kabupaten Lombok Barat (2) mengidentifikasi hambatan-hambatan dalam penanganan korban perilaku (bullying) pada siswa SMP Negeri Kecamatan Kediri Kabupaten Lombok Barat. Metode yang di gunakan dalam penelitian ini pendekatan kualitatif. Lokasi penelitian dilaksanakan di SMP Kecamatan Kediri Kabupaten Lombok Barat. Penentuan informan dengan menggunakan snowball. Metode pengumpulan data yaitu depth interview), observation and documentation. Hasil Penelitian telah dianalisis maka didapatkan: (1) melakukan penyeleksian informasi (supporting network).(2) melakukan
\end{abstract}




\section{Muhammad Mabrur Haslan, Ahmad Fauzan, I Nengah Agus Tripayana.}

tahap pendampingan atau peer monitoring. (3) melakukan pemanfaatan kelompok teman atau peer befriending. (4) melakukan konseling dan mediasi.(5) melakukan sosialisasi dan kontrol, yaitu upaya pembekalan pemahaman dan pemantauan secara terus menerus kepada korban bullying pada pihak sekolahnya.

Kata Kunci: pola penanganan; korban perilaku bullying

Diterima 26 April 2021, Dipublikasikan April 2021

\section{PENDAHULUAN}

Salah satu yang menyita perhatian publik sekarang ini adalah terjadinya kekerasan atau perilaku bullying di sekolah, baik yang dilakukan oleh guru terhadap siswa, maupun yang dilakukan siswa terhadap siswa lainnya. Merebaknya kasus bullying melalui media cetak maupun elektronik pada siswa di sekolah telah menjadi lunturnya nilai-nilai kemanusiaan. Kasus kekerasan tersebut dapat mencoreng citra pendidikan di Indonesia selama ini dianggap mampu mewadahi proses humanisasi, sehingga banyak menimbulkan pertanyaan mengenai produktivitas pendidikan disekolah dewasa ini.

Sejumlah sekolah di Indonesia dalam beberapa bulan terakhir ini. Kasus bullying yang dilakukan siswa SMPN 16 Malang, di mana. pelaku mengangkat korban secara bersama-sama lalu dilempar ke paving, kemudian diangkat lagi dan dilempar ke pohon. Perbuatan pelaku menyebabkan jari tengah sebelah kanan korban mati rasa atau tidak berfungsi sehingga harus dilakukan amputasi. Pelaku ditetapkan sebagai tersangka dengan inisial WS dan RK. Belum lama kita juga dihebohkan dengan video kasus bullying siswi SMP Muhammadiyah Purwerejo", yaitu seorang siswi dipukul dan ditendang tiga siswa. Ketiganya telah ditetapkan sebagai tersangka yang berinisial TP (16), DF (15) dan UH (15). Ketiganya disangkakan melanggar pasal 80 Undang-Undang Perlindungan Anak tentang kekerasan terhadap anak. Ancaman hukumannya adalah 3 tahun dan 6 bulan penjara (Sumber: CNN Indonesia).

Berangkat dari kasus-kasus yang terjadi, Indonesia digolongkan dalam darurat bullying, hal ini ditandai dengan meningkatnya angka kasus bullying tiap tahunnya. Belum lagi kasus-kasus yang tidak terekam atau kasus yang tidak diangkat ke permukaan. Indonesia termasuk negara yang memiliki peringakt tertinggi terjadinya kasus bullying di ASEAN, hal ini di sampaikan oleh United Nation Internasional Children's Emergency Fund (UNICEF) 2016, Indonesia di Peringkat Pertama untuk soal kekerasan pada anak. Sasaran praktik bullying di sekolah adalah para siswa yang memiliki keunikan secara fisik. Misalnya cacat secara fisik dan lain sebagainya. Kemudian dilihat dari perbedaan golongan seperti, agama, ras, suku, dan lain-lain.

Praktik bullying juga kerap kali terjadi pada siswa baru atau adik kelas. Perilaku yang pemiliar (sering terjadi) pada kalangan remaja adalah mengucilkan atau memojokkan siswa yang baru masuk. Hal ini juga sering dilakukan untuk mengajari adik kelas mereka tentang berperilaku sopan santun di dalam sekolah. Banyak pihak sekolah tidak memahami persoalan tersebut yang sering dilakukan oleh siswa lama, dan kadang kala kerap di jadikan suatu hal 


\section{Pola penanganan korban perilaku (bullying) pada Siswa SMPN Kecamatan Kediri Kabupaten Lombok Barat.}

yang biasa oleh pihak sekolah karena dulu mereka pernah mengalami persolan tersebut.(Faturrochman, 2012).

Menurut Zakiyah dkk, 2017. faktor-faktor penyebab terjadinya bullying adalah: pertama, faktor orang tua (keluarga) yang sering memberikan hukuman yang berlebihan, situasi rumah tangga mereka yang penuh tekanan atau protektif. Kedua ketidak pedulian sekolah terhadap persoalan bullying sehingga tidak ada sangsi tegas yang diberikan kepada siswa tersebut, sehingga mereka merasa lebih bebas untuk melakukan apa saja yang sebanarnya merupakan perilaku yang terlarang. Ketiga, adanya kebiasaan berintegrasi dilingkungan rumah mereka yang teman-teman sebayanya. Keempat, lingkungan sosial mereka yang tidak permasalahkan tindakan bullying tersebut.. Hal tersebut relevan dengan pendapat Mabrur et. all. (2019) menyatakan bahwa faktor pendorong pelaku melakukan tindakan bullying, yaitu: pertama, faktor perceraian orang tua atau karena orang tuanya pergi TKI. Kedua, faktor ekonomi, di mana pelaku berasal dari keluarga yang memiliki ekonomi lemah. Ketiga, faktor kelompok atau gank, dimana pelaku berani melakukan kekerasan bullying karena didukung oleh kelompoknya. Keempat, faktor media. Adanya tayangan kasus tindakan kekerasan di media memberikan dorongan kepada pelaku melakukan hal yang sama.

Perilaku bullying tentu berdampak pada korban, baik dampak fisik dan psikologis. Berdasarkan hasil studi pendahuluan, yang dilakukan peneliti di SMPN yang ada di Kecamatan Kediri dampak perilaku bullying pada siswa SMPN Kediri terlihat pada psikologis, sosial, serta fisik. Akibatnya korban menjadi depresi, cemas yang berlebihan sehingga dapat mempengaruhi motivasi dan hasil belajar. Dengan demikian dapat berdampak pada kepercayaan siswa untuk ke sekolah sehingga berupaya untuk menghindari dari lingkungan sekolah. Dampak dari perlakuan bullying terlihat pada kekerasan fisik seperti, lebam pada bagian tubuhnya. Sedangkan dampak psikologis terlihat dari rasa cemas yang berlebihan, minder, dan hilang kepercayaan diri. Sehingga ingin menjauhi dari lingkungan teman-teman mereka (Observasi, 2019).

Sedangkan dampak akademik korban perilaku bullying adalah kurang semangatnya mengikuti pembelajaran, kurang aktif, hilangnya motivasi belajar, dengan kondisi demikian dapat membuat siswa ingin pindah ke sekolah lain. Hal ini sejalan dengan pendapat Coloroso (2006) korban bullying akan merasa emosional, marah terhadap dirinya sendiri, terhadap pelaku bullying, bahkan kepada orang-orang sekitar lingkungan mereka yang dianggap tidak mampu menolong mereka yang terkena bullying. Dampak bullying ini akan mengakibatkan ketidak sadarannya atas pengaruh prestasi belajar akademik sekolah membuat mereka akan menarik diri dari lingkungan sekitar.

Mencermati dampak bullying yang menimpa korban maka diperlukan pola penanganan yang tepat agar tidak berlarut-larut. Apabila korban bullying tidak segera ditangani maka dampaknya tambah parah lagi. Bahkan ada korban juga sampai bunuh diri gara-gara penanganannya terlalu lamban. Tentunya kita berharap tidak terjadi lagi. Kita tidak menginginkan ada persoalan yang satu belum tuntas sementara muncul persoalan baru. 


\section{Muhammad Mabrur Haslan, Ahmad Fauzan, I Nengah Agus Tripayana.}

Berdasarkan studi pendahuluan yang dilakukan peneliti, banyak orang tua murid yang melapor ke sekolah karena anaknya menjadi korban kekerasan (Bullying) sama teman-temannya, seperti kasus pemalakan, penganiayaan atau pemukulan.

Dari uraian tersebut di atas maka permasalahan dalam penelitian ini adalah sebagai berikut: (1) Bagaimana pola penanganan korban perilaku (bullying) pada siswa SMP Negeri Kecamatan Kediri Kabupaten Lombok Barat (2) Apa hambatan-hambatan dalam penanganan korban perilaku (bullying) pada siswa SMP Negeri Kecamatan Kediri Kabupaten Lombok Barat.

\section{METODE}

Pendekatan yang digunakan dalam penelitian adalah kualitatif, yaitu fenomena apa yang di lakukan oleh subyek penelitian. Seperti, persepsi, perilaku, serta tindakan deskriptif dalam membangun narasi pada suatu konteks alamiah dan memanfaatkan metode ilmiah. (Nazir, 1998:64). Subjek penelitian adalah sumber tempat kita memperoleh keterangan atau pengungkap informasi yang telah dipilih menurut keinginan peneliti dan merupakan sumber pewarta yang sangat diharapkan oleh para peneliti untuk mengungkapkan secara leluasa dan panjang lebar sebatas yang diinginkan peneliti (Faisal, 1999: 50).

Subjek penelitian ini adalah guru Bimbingan Konseling dan Guru PPKn. Sedangkan informan penelitian adalah satu orang menjawab pertanyaan-pertanyaan dari keterangan seorang ahli, yang mengetahui peristiwa yang mereka alami dalam lingkungan sosial budaya mereka. Informan penelitian ialah sumber pertama dari seseorang yang bicara dengan katakata, frasa, serta kalimat dialeknya sebagai sumber informasi sebagai model imitasi. (Moleong, 2000: 12)

Penentuan informan, pertama dilakukan secara purposive berdasarkan pertimbangan peneliti dan memenuhi kriteria yang ditentukan peneliti, yaitu mengetahui dengan baik tentang pola penanganan korban perilaku pada siswa SMPN Kecamatan Kediri Kabupaten Lombok Barat. Kemudian penentuan informasi berikutnya dengan menggunakan snowball, yaitu menemukan data yang diinginkan dengan menentukan informasi berdasarkan informan pertama, kemudian menentukan informasi kedua berdasarkan informasi pertama, informasi ketiga berdasarkan informasi kedua begitu seterusnya sampai memperoleh banyak informan, sehingga data yang diperoleh jelas dan valid. Informan dalam penelitian ini adalah siswa korban dan pelaku perilaku (bullying), Kepala Sekolah, Wakil Kepala Sekolah. Pengumpulan data penelitian dilakukan melalui: Pertama, wawancara mendalam (depth interview), Kedua, observasi (observation) dan ketiga studi dokumen. Teknik analisa data dilakukan dalam suatu proses yakni pelaksanaannya sudah mulai dikerjakan sejak pengumpulan data dilakukan secara intensif sampai setelah pengumpulan data. Proses analisis ini dilakukan hampir secara berbarengan dengan interpretasi data yang dikerjakan dengan secepatnya tanpa harus menunggu banyaknya data terkumpul. Data yang diperoleh melalui penelusuran informasi mengenai dampak perilaku (bullying) bagi siswa. Dalam konteks ini juga dikaji faktor-faktor 


\section{Pola penanganan korban perilaku (bullying) pada Siswa SMPN Kecamatan Kediri Kabupaten Lombok Barat.}

mempengaruhi perilaku (bullying) dan dampaknya bagi siswa SMP Kecamatan Kediri Kabupaten Lombok Barat. Data kualitatif yang tersusun dalam kelompok fenomena dan ungkapan-ungkapan yang dinyatakan oleh guru bimbingan konseling dan guru PPKn terkait pola penanganan korban pelaku perilaku (bullying) (interpretasi emik) dipakai dasar untuk menyusun deskripsi menurut persepsi peneliti (interpretasi etik) tentang pola penanganan korban pelaku perilaku (bullying) pada siswa SMP Kecamatan Kediri Kabupaten Lombok Barat.

\section{HASIL DAN PEMBAHASAN}

\section{Pola Penanganan Korban Perilaku (Bullying) Pada Siswa SMPN Kecamatan Kediri Lombok Barat}

Perilaku bullying dapat melemahkan seseorang inidividu atau kelompok dalam melakukan tindakan di luar kehendak mereka, bertujuan untuk membahayakan mental dan fisik orang lain. Hampir orang tua tindak menyadari anak mereka menjadi korban bullying disekolah. Bentuk umum dari penindasan tersebut adalah pelecehan verbal dalam bentuk meledek penyebutan nama atau merendahkan teman sehingga dapat menimbulkan kekerasan seperti menendang.

Bullying menjadi suatu tindakan yang tidak baik/menyimpang dalam pergaulan sosial siswa, jika dilihat dalam jangka pendek bullying ini dapat menimbulkan rasa tidak aman, menderita stress, bahkan depresi yang mengakibatkan bunuh diri. Sedangkan jangka panjang penderitaan emosional yang dialami oleh korban perilaku bullying. (Ratna Djuwita, 2006).

Berdasarkan hasil penelitian bahwa pola penanganan korban perilaku bullying yang dilakukan oleh Guru BK atau Guru PPKN di SMPN Kecamatan Kediri Kabupaten Lombok Barat, melewati tahapan sebagai berikut: Pertama, melakukan penyeleksian informasi (supporting network). Pada tahap ini, melakukan pemanggilan kepada siswa yang terlibat langsung dengan kasus perilaku bullying, pekaku dan korban Untuk memastikan kasus itu pihak sekolah juga memanggil teman-temannya yang lain yang ikut menyaksikan kejadian itu. Hal ini bertujuan untuk mengklarifikasi keadaan yang sebenarnya terjadi, sehingga keduanya tidak bisa berdalil tanpa fakta. Hal ini diungkapkan subyek penelitian SHR, sebagai berikut:

\footnotetext{
"Langkah awal yang kami lakukan adalah memanggil, korban, pelaku dan saksi yang menyaksikan terjadinya kasus bullying. Untuk mengklarifikasi persoalan itu," atau untuk mengetahui kronologis kejadian itu". (Wawancara, 5 Agustus 2020).
}

Selain pernyataan yang diungkapkan Pak SHR, seorang guru BK yang berinisial HSN menjelaskan hal yang sama terkait dengan pola penanganan perkara perilaku bullying siswa di sekolah, dengan melakukan pemanggilan kepada kedua belah pihak di ruangan BK. Kemudian guru BK mempersilahkan satu persatu untuk menyampaikan kronologis munculnya permasalahan tersebut, seperti yang diungkapkan guru BK dengan inisial HSN, sebagai berikut: 


\title{
Muhammad Mabrur Haslan, Ahmad Fauzan, I Nengah Agus Tripayana.
}

\begin{abstract}
"Tahap awal kami lakukan adalah melakukan pemanggilan kepada pelaku dan korban bullying, untuk diminati keterangan masing-masing, lalu untuk mengklarifikasi kasus itu kami membutuhkan teman yang ada di sekitarnya untuk memaparkan kronologis peristiwa itu." (Wawancara, 9 September 2020)
\end{abstract}

Kedua, pola penanganan korban perilaku bullying adalah dengan melakukan tahap pendampingan atau peer monitoring. Pada tahap ini baik guru BP atau PPKN SMPN Kediri, melakukan pembinaan mental agar korban bullying senantiasa tidak depresi atau shock, atas perilaku bullying yang menimpanya. Kemudian proses pendampingan dilakukan sampai dengan memastikan bahwa korban bullying tidak mengalami depresi atau shock akibat perilaku bullying siswa yang di alaminya dengan kurun waktu maksimal 1 bulan. Hal ini diungkapkan oleh Guru BK dengan inisial RD sebagai berikut:

"Dalam tahap pendampingan ini kami sebagai Guru BK, melakukan pembinaan agar korban tidak mengalami depresi, trauma dengan kejadian yang menimpanya". (Wawancara, 11 Agustus 2020)

Terkait dengan hal tersebut kepala sekolah SMPN 2 Kediri dengan inisial (HLS) juga mengungkapkan persoalan yang sama terkait tahap pendampingan yaitu melakukan pendampingan kepada korban seperti pembinaan mental agar korban bullying senantiasa tidak depresi atau shock, atas perilaku bullying yang menimpanya. Adapun pihak yang terlibat dalam hal ini adalah kepala sekolah, guru PPKn, guru BK, wakil kepala kesiswaan dan pihak keluarga dari si korban. Kemudian proses pendampingan dilakukan sampai dengan memastikan bahwa korban bullying tidak mengalami depresi atau shock akibat perilaku bullying siswa yang di alaminya dengan kurun waktu maksimal 1 bulan, sebagaimana yang diungkapkan Kepala Sekolah SMPN 2 Kediri dengan inisial HLS, sebagai berikut:

\footnotetext{
"Bentuk' pendampingan yang kami lakukan adalah dengan melakukan pembinaan mental agar korban bullying senantiasa tidak depresi atau shock, atas perilaku bullying yang menimpanya sampai kurun maksimal 1 bulan” (Wawancara, 19 Agustus 2020).
}

Ketiga, pola penanganan korban perilaku bullying dengan melakukan pemanfaatan kelompok teman atau peer befriending. Pada tahap ini, memanfaatkan suatu kelompok teman untuk senantiasa melindungi, mendampingi, menjaga murid-murid yang kecil dan lemah yang rentan sebagai korban bullying melalui aktivitas support dan memperluas pertemanan. Bentuk pemanfaatan kelompok teman adalah dengan membentuk kelompok keamanan kelas di setiap kelas yang ada, baik dari kelas VII sampai dengan kelas IX, yang tujuannya adalah untuk mengamankan kelas umumnya dan melindungi korban bullying khususnya dari kemungkinan terjadinya perilaku bullying lagi. Adapun pihak yang dilibatkan dalam hal ini adalah guru PPKn yakni saya sendiri, guru BK, waka kesiswaan, dan siswa. Kemudian proses pemanfaatan kelompok teman melalui pembentukan kelompok keamanan kelas ini kami lakukan sampai 


\title{
Pola penanganan korban perilaku (bullying) pada Siswa SMPN Kecamatan Kediri Kabupaten Lombok Barat.
}

dengan perilaku bullying sudah tidak terjadi lagi di lingkungan sekolah, atau dengan kurun waktu maksimal 1 bulan. Hal ini diungkapkan guru PPKn dengan inisial SHR, sebagai berikut:

\begin{abstract}
"Pada tahap pemanfaatan kelompok teman atau peer befriending. kami membentuk kelompok keamanan kelas di setiap kelas dengan tujuannya mengamankan kelas umumnya dan melindungi korban bullying dalam kurun waktu maksimal 1 bulan." (Wawancara, 21 Agustus 2020).
\end{abstract}

Terkait dengan hal tersebut (HLS) selaku Kepala Sekolah SMPN 2 Kediri, juga menjelaskan Bentuk pemanfaatan kelompok teman yang kami lakukan khususnya adalah, kami membentuk kelompok keamanan kelas di setiap kelas yang ada, baik dari kelas VII sampai dengan kelas IX, yang tujuannya adalah untuk mengamankan kelas umumnya dan melindungi korban bullying khususnya dari kemungkinan terjadinya perilku bullying lagi. Adapun pihak yang dilibatkan dalam hal ini adalah kepala sekolah yakni saya sendiri, guru PPKn, guru BK yakni saya sendiri, waka kesiswaan, dan siswa. Kemudian proses pemanfaatan kelompok teman melalui pembentukan kelompok keamanan kelas ini kami lakukan sampai dengan perilaku bullying sudah tidak terjadi lagi di lingkungan sekolah, atau dengan kurun waktu maksimal 1 bulan."

Keempat, pola penanganan korban perilaku bullying dengan melakukan konseling dan mediasi. Guru BK memiliki peranan penting Tujuan Umum bimbingan dan konseling sebagaimana yang dinyatakan dalam Undang-Undang Sistem Pendidikan Nasional (UUSPN) Tahun 1989, yaitu terwujudnya manusia Indonesia seutuhnya, yang cerdas, yang beriman dan bertakwa kepada Tuhan Yang Maha Esa dan berbudi pekerti luhur, memiliki pengetahuan dan ketrampilan, kesehatan jasmani dan rohani, kepribadian yang mantap dan mandiri seta rasa tanggung jawab kemasyarakatan dan kebangsaan (Depdikukbud, 1994: 5). Sedangkan tujuan khusus bimbingan dan konseling untuk membantu siswa agar dapat mencapai tujuan-tujuan perkembangan meliputi aspek pribadi, sosial, belajar, dan karier.

Kegiatan konseling yang dilakukan oleh Guru BP maupun Guru PPKn untuk memulihkan kembali dan kepercayaan diri korban dari traumatis dari dampak perilaku bullying, menghilangkan rasa takut, depresi yang sudah diderita korban. Hal ini diungkapkan oleh SHR sebagai guru PPKN, y]sebagai berikut:

\footnotetext{
"Kita melakukan konseling kepada korban, supaya bangkit semangatnya untuk belajar, menghilangkan traumatis, percaya diri yang hilang selama ini, yang lebih penting lagi adalah menghilangkan depresi yang berlebihan”. (Wawancara, 29 Agustus 20020).
}

Konseling individual sebagai jantung hatinya layangan bimbingan konseling di sekolah yang diselenggarakan oleh guru pembimbing/konselor sekolah membahas segala apa yang telah terjadi. Istilah investigasi dimaksudkan adalah menelusuri sedalam-dalamnya dan seluasluasnya apa yang dirasakan dan dialami korban bullying. Kemudian mediasi dalam penanganan korban perilaku bullying ini dimaksudkan adalah sebagai upaya untuk menyelesaikan 


\section{Muhammad Mabrur Haslan, Ahmad Fauzan, I Nengah Agus Tripayana.}

persoalan yang terjadi, yaitu dalam hal ini persoalan bullying. Mediasi ini dilakukan dengan memanggil orang tua korban, korban bullying, orang tua pelaku, dan pelaku korban bullying.

Berbeda dengan mediasi yang dilakukan dalam penyelesaian kasus bullying, yang terjadi di SMPN 2 Kediri, di mana pihak sekolah memanggil orang tua korban, korban perilaku bullying, orang tua pelaku, pelaku korban, dan pihak kepolisian. Keterlibatan pihak kepolisian ini, disebabkan karena kasus bullying yang terjadi dipublikasikan atau dilakukan perekaman oleh teman pelaku bullying sehingga kasus ini dianggap pihak terlalu parah. Apalagi kasus ini sudah dipublikasi di medsos oleh teman pelaku bullying. Untuk mengantisipasi supaya rekaman video kasus bullying ditonton oleh banyak orang, maka pihak SMPN 2 Kediri meminta aparat kepolisian untuk ikut terlibat secara langsung dalam menyelesaikan kasus bullying. Dalam pertemuan di sepakati, supaya rekaman video kasus bullying di SMPN Kediri, untuk segera dihapus oleh pengguna akun, apabila mengulangi maka akan diberikan sanksi untuk tidak naik kelas. Hal ini diungkapkan Kepala Sekokah SMPN 2 Kediri sebagai berikut:

\footnotetext{
"Penyelesaian kasus bullying, dilakukan melalui mediasi dengan melibatkan Kepala Sekokah, Guru BP, Guru PKN, orang tua korban, korban bullying, orang tua pelaku, pelaku bullying, siswa yang terlibat langsung melakukan perekaman video kasus bullying, dan aparat kepolisian. Kami melibatkan banyak pihak karena perekaman video kasus bullying sudah diupload teman pelaku, sehingga untuk mengantisipasi supaya video kasus bullying ditonton banyak orang, memerlukan penyelesaian yang sangat serius." (Wawancvara, 5 September 2020)
}

Kelima, Pola penanganan perilaku bullying dengan melakukan sosialisasi dan kontrol, yaitu upaya pembekalan pemahaman dan pemantauan secara terus menerus kepada korban bullying. Untuk terlaksana pola tersebut, pihak sekolah menyelenggarakan sosialisasi tentang bahaya perilaku bullying yang dalam hal ini melibatkan pihak kepolisian yakni Kapolsek Kediri, guru PPKn, guru BK, waka kesiswaan, kepala sekolah dan siswa/siswi SMPN 1 dan SMPN 2 Kediri. Sedangkan kontrol atau pengawasan yang dilakukan pihak sekolah dengan tetap memantau perkembangan anak khususnya korban bullying dalam hal ini sampai dengan berakhirnya permasalahan bullying yang terjadi di sekolah dan memastikan korban tetap baik-baik saja dalam keadaan normal seperti biasanya. Hal ini diungkapkan oleh Guru SHR, sebagai berikut:

"Dalam menangani kasus bullying, kami juga menyelenggarakan sosialisasi tentang bahaya perilaku bullying dengan bekerja sama dengan pihak kepolisian, Sedangkan dalam hal kontrol atau pengawasan, kami melakukan pemantauan atau pengawasan setiap hari untuk mengevaluasi adanya kasus yang muncul di sekolah, pihak selalu sigap terhadap persoalan kasus bullying. "(Wawancara, 7 September 2020).

Hal yang sama juga diungkapkan oleh Guru BK SMPN 1 Kediri, yang berinisial HSN, bahwa upaya penganganan kasus bullying, pihak sekolah selalu melibatkan pihak kepolisian dalam melakukan sosialisasi terkait= dampak perilaku bullying. Pengawasan dilakukan oleh guru untuk memperhatikan setiap perilaku yang dilakukan siswa baik yang pernah menjadi pelaku bullying maupun siswa lainnya. Pengawasan dilakukan secara terus menerus oleh guru agar dapat memantau perilaku siswa dengan maksimal supaya setiap saat dapat terhindar dari kemungkinan melakukan bullying atau sebagai korban bullying. Dalam pengawasan tersebut pihak sekolah juga melibatkan guru, wali kelas, untuk senantiasa memantau atau mengawasi 


\section{Pola penanganan korban perilaku (bullying) pada Siswa SMPN Kecamatan Kediri Kabupaten Lombok Barat.}

setiap waktu munculnya kasus bullying di sekolah. Hal ini diungkapkan, oleh Guru BP, HSN, sebagai berikut:

\footnotetext{
"Upaya penanganan kasus bullying, kit bekerja sama dengan pihak kepolisian Kediri untuk melakukan sosialisasi dampak atau bahaya bullying terhadap siswa. Sedangkan terkait kontrol atau pengawasan, kami bekerja sama dengan guru, wali kelas untuk selalu memantau dan mengawasi kasus bulying”. (Wawancara, 9 September 2020).
}

Bulliying yang semakin mengkhawatirkan perlu segera di atasi agar dampak yang terjadi ketika mengalami bullying, emosional tinggi, gangguan psikologis, serta kecemasan yang terlalu berlebihan dapat diantisipasi (Bulu et al., 2019).

\section{Hambatan dalam penanganan korban perilaku bullying pada siswa SMPN Kecamatan Kediri Kabupaten Lombok Barat}

Dalam menangani periaku bullying yang dilakukan pada siswa SMPN 1 dan SMPN 2 Kediri terdapat hambatan-hambatan sebagai berikut: pertama, tidak terbukanya korban bullying untuk melaporkan kepada guru. Hal ini disebabkan ada malu, diam dan tidak berani melaporkan perlakuan yang dialaminya kepada guru atau guru BP. Siswa yang takut melaporkan perlakuan bullying yang dialaminya menyebabkan kesulitan dalam menangani kasus bulllying terjadi. Sebagaimana pernyataan Bu Erna sebagai guru BP yang menyatakan ketidakterbukaan siswa melaporkan ke guru, berikut pemaparan Bu Erna:

\footnotetext{
"Kita kesulitan menangani korban perilaku bullying ini pak, karena kadang-kadang siswa korban bullying tidak mau terbuka dan malu melaporkan kasusnya kepada guru-guru. Sehingga hal ini yang menjadi hambatan kita dalam menangani kasus bullying di sekolah pak." (Wawancara, 3 Oktober 2020).
}

Pernyataan Bu Erna dipertegas oleh Guru PPKn yang bernama H. Sahar, berikut pernyaraan pak H. Sahar:

\footnotetext{
"Hambatannya itu terkadang disebabkan karena korban merasa malu atau tidak mau berterus terang kalau kasus yang terjadi pada dirinya." (Wawancara, 12 Oktober 2020).
}

Penanaman sifat berani, dan terbuka harus ditanamkan sejak dini mulai dari lingkungan keluarga, sampai lingkungan sekolah. Sehingga kalau siswa sudah tertanam sifat berani dan terbuka, maka ketika mendapat perlakuan yang tidak etis dan kekerasan ia berani melawan dan melapor kepada guru baik guru BP maupun guru lain di sekolah (Bulu, et. al, 2019).

Kedua, Kesulitan mengawasi perilaku siswa pada saat berada di luar lingkungan sekolah. Berbagai perilaku masih bisa terkontrol jika berada di lingkungan sekolah. Namun ketika berada di luar lingkungan sekolah, guru mengalami kesulitan dalam mengawasi perilaku siswa, karena pengawasan sepenuhnya diserahkan kepada orang tua siswa. Hal tersebut menjadi hambatan guru dalam menangani perilaku bullying di SMPN 1 dan SMPN 2 Kediri Lombok Barat. Hal ini sesuai dengan pernyataan Pak Hasan sebagai berikut: 


\title{
Muhammad Mabrur Haslan, Ahmad Fauzan, I Nengah Agus Tripayana.
}

\begin{abstract}
"Hambatan yang kita hadapi dalam menangani perilaku bullying, ketika siswa sudah berada di luar sekolah. Apabila siswa sudah berada di luar sekolah, maka pengawasan sepenuhnya diserahkan kepada orang tua siswa. Jadi kita tahu apa yang di lakukan selama berada di rumah." (Wawancara, 21 Oktober 2020).
\end{abstract}

Pernyataan Pak Hasan dipertegas oleh Bu Erna terkait dengan kesulitan pengawasan perilaku siswa yang berada di rumah. Pernyataan Bu Erna sebagai berikut:

"Kalau di lingkungan sekolah masih bisa kita awasi perilaku bullying, tapi jika berada di luar lingkungan sekolah susah untuk mengontrolnya kita siswa sudah berada di rumahnya, karena kita tahu apa yang mereka lakukan." (Wawancara tanggal 25 Oktober 2020).

Ketiga, Hambatan yang terakhir adalah kurang pemahaman guru bahaya bullying di sekolah. Bullying atau tindakan kekerasan yang muncul oleh karena individu yang memiliki kekuasaan dapat muncul dalam berbagai bentuk, baik secara verbal, maupun non verbal, seperti mengolok dengan sebutan nama orang tua, kekerasan fisik, penganiayaan dan lain-lain. Terkadang pemahaman guru terhadap perilaku pengolokan siswa dengan menyebut nama orang tua dianggap sebagai bahan candaan, sehingga menganggap sepele. Berikut pernyataan pak Sahar, sebagai berikut:

"Masih terdapat guru-guru yang paham akan bahaya bullying, tidak sedikit guru menganggap bullying sebagai bahan candaan sehingga siswa malu untuk melaporkan ke guru kalau dirinya sebagai menjadi korban bullying." (Wawancara, 27 Oktober 2020).

Pernyataan Pak Sahar dipertegas oleh pernyataan Bu Erna. Berikut pernyataan Bu Erna.

"Hambatannya masih ada guru yang menganggap kalau bullying itu cuma hal sepele, yang menganggap sebagai sebuah candaan antar teman. Padahal candaan itu berdampak pada psikologis siswa, seperti malu, minder dan kurang percaya diri." (Wawancara, tanggal 29 Oktober 2020).

Berdasarkan pernyataan Pak Sahar dan Bu Erni dapat disimpulkan memanggil nama dengan sebutan lain atau nama orang tua dianggap sebagai suatu yang biasa saja. Padahal hal tersebut termasuk bullying verbal berdampak pada psikologis siswa. Pengetahuan tentang bullying dan bahaya bullying perlu disampaikan para guru.

\section{SIMPULAN}

Berdasarkan hasil dan pembahasan penelitian dapat disimpulkan beberapa hal sebagai berikut, yaitu pola penanganan korban perilaku bullying pada siswa SMPN Kecamatan Kediri, sebagai berikut: Pertama, melakukan penyeleksian informasi (supporting network). Pada tahap ini, melakukan pemanggilan kepada siswa yang terlibat langsung dengan kasus perilaku 


\section{Pola penanganan korban perilaku (bullying) pada Siswa SMPN Kecamatan Kediri Kabupaten Lombok Barat.}

bullying, pekaku dan korban Untuk memastikan kasus itu pihak sekolah juga memanggil teman-temannya yang lain yang ikut menyaksikan kejadian itu. Kedua, melakukan tahap pendampingan atau peer monitoring. Pada tahap ini baik guru BP atau PPKN SMPN Kediri, melakukan pembinaan mental agar korban bullying senantiasa tidak depresi atau shock, atas perilaku bullying yang menimpanya. Ketiga, melakukan pemanfaatan kelompok teman atau peer befriending. Pada tahap ini, memanfaatkan suatu kelompok teman untuk senantiasa melindungi, mendampingi, menjaga murid-murid yang kecil dan lemah yang rentan sebagai korban bullying melalui aktivitas support dan memperluas pertemanan. Keempat, melakukan konseling dan mediasi. Tujuannya untuk memulihkan kembali dan kepercayaan diri korban dari traumatis, rasa takut, depresi dari dampak perilaku bullying. Kelima, melakukan sosialisasi dan kontrol, yaitu upaya pembekalan pemahaman dan pemantauan secara terus menerus kepada korban bullying.

Hambatan dalam menangani korban perilaku bullying antara lain: pertama, tidak terbukanya korban bullying untuk melaporkan kepada guru. Hal ini disebabkan ada malu, diam dan tidak berani melaporkan perlakuan yang dialaminya kepada guru atau guru BP. Kedua, kesulitan mengawasi perilaku siswa pada saat berada di luar lingkungan sekolah. Ketiga, kurang pemahaman guru tentang bahaya bullying di sekolah. Terkadang pemahaman guru terhadap perilaku pengolokan siswa dengan menyebut nama orang tua dianggap sebagai bahan candaan, sehingga menganggap sepele, sehingga berdampak terhadap psikologis korban.

\section{DAFTAR PUSTAKA}

Bimo, Walgito, 2003, Pengantar Psikologi Umum, Yogyakarta, Andi.

Bulu, Y., Maemunah, N., \& Sulasmini. (2019). Faktor-faktor yang Mempengaruhi Perilaku Bullying pada Remaja Awal. Nursing News.

Colorosa, Barbara., 2006, Penindas, Tertindas, dan Penonton (Resep Memutuskan Rantai

Kekerasan Anak dari Prasekolah Hingga SMU), Serambi Ilmu Pustaka.

Colorosa, Barbara., 2007, The Bully,The Bullied, and The Bystander, New York, Harper Collins.

Faisal, Sanapiah, (1990), Penelitian Kualitatif (Dasar-dasar dan Aplikasi), Yayasan Asah Asuh, Malang.

Faturochman, 2012, Psikologi Untuk Kesejahteraan Masyarakat, Yogyakarta, Pustaka Pelajar.

Geldard, Kathryn. 2012. Konseling Remaja Intervensi Praktis Bagi Remaja

Beresiko.Yogyakarta: Pustaka belajar.

Kalliotis, P, 2000, “Bullying as a Spesial Case of Aggresion, Sage publication Volume 21, No. 1 April 2000.

Muhammad Mabrur Haslan, 2009, Kajian Tentang Kekerasan Pada Anak ( Studi Perlakuan Salah (Child Abuse) Orang Tua Terhadap Anak Pada Keluarga Kawin-Cerai di Masyarakat Suku Sasak, Laporan Hasil Penelitian, FKIP Universitas Mataram. 


\section{Muhammad Mabrur Haslan, Ahmad Fauzan, I Nengah Agus Tripayana.}

Muhammad, M, 2009, Aspek Perlindungan Anak Dalam Tindak Kekerasan (Bullying)

Terhadap Siswa Korban Kekerasan di Sekolah, Jurnal Dinamika Hukum.

Moleong, Lexy, J. (1996), Metodologi Penelitian Kualitatif, Remaja Rosda Karya, Bandung.

Nazir, Muh., 1988, Metode Penelitian, Ghalia Indonesia, Jakarta.

Notoatmodjo, Soekidjo, 2010, Ilmu Perilaku Kesehatan, Jakarta:Rineka Cipta.

Ratna Djuwita, 2006, Kekerasan Tersembunyi Di Sekolah, Aspek-Aspek Pdikososial Dari Bullying-Victims: A Comparison of Psychosocial and Behavioral Characteristic, Journal of Pediatric Phychology.

Sejiwa, 2008, Bullying, Mengatasi Kekerasan di Sekolah dan Lingkungan Sekitar Anak, Jakarta, Gramedia.

Sindo News, 24 Juli 2018

Widyatun, T.R, 1999, Ilmu Perilaku, Jakarta, CV. Agung Seto.

Zakiyah, Ela Zain, et all, 2017, Faktor Yang Mempengaruhi Remaja Dalam Melakukan Bullying, Jurnal Penelitian dan PPM UNPAD, ISSN : 2442-448X, Vol. No. 2. Juli 2017 